\title{
Research on the Debris Flow Hazards after the Wenchuan Earthquake in Bayi Gully, Longchi, Dujiangyan, Sichuan Province, China
}

\author{
$\mathrm{Yu} \mathrm{Ma}^{*}$ and Caixia Li \\ The Engineering \&Technology of College of Chengdu University of Technology, Leshan 614000, China \\ *Corresponding author
}

\begin{abstract}
Many debris flow hazards were triggered in Earthquake area after the Wenchuan Earthquake. In these debris flow hazards, the most notable one is the debris flow in Bayi Gully on Aug.13, 2010. Bayi Gully was a debris flow gully before the Wenchuan Earthquake, in the first three raining seasons after the Wenchuan Earthquake, there are 4 times debris flows were triggered, and the largest and most harmful debris flow was triggered on August 13, 2010. The total rainfall during the debris flow of August 13 was $229 \mathrm{~mm}$, and the duration of debris flow was 1 hour and $40 \mathrm{~min}$. The density of debris flow was $1.88 \mathrm{~g} \cdot \mathrm{cm}^{-}$ ${ }^{3}$,the discharge is $1082 \mathrm{~m}^{3} \cdot \mathrm{s}^{-1}$, the yield stress of debris flows is more than $6700 \mathrm{~Pa}$, The volume of debris flow was 1.16 million cubic meter. The debris flow claimed 2 people are lost, 1 people is wounded, 140 houses are seriously destroyed, DuWen road were silted and check dams, drainage engineering were destroyed. And 15 million (RMB) economic lost. Only $30 \%$ sediment of debris deposition was taken away by the 4 times debris flows. New debris flow will be triggered by rainfall in Bayi Gully in the future. It will be a long term work to prevent the debris flows in Bayi Gully
\end{abstract}

Keywords-Wenchuan Earthquake; debris flow; formation; characteristics; prediction

\section{INTRODUCTION}

Debris flows are ubiquitous hazards in mountain areas. On August 13, 2010 heavy rainfall occurred in the Longxi River catchment: the maximum rainfall intensity in one hour was $75.0 \mathrm{~mm}$, the cumulative rainfall was $229 \mathrm{~mm}$ and the duration of debris flow was 1 hour $40 \mathrm{~min}$. The rainfall triggered 45 debris flows. The total volume of the debris flow deposits was $3.34 \times 10^{6} \mathrm{~m}^{3}$. A lot of sediments were deposited in the downstream part of the Longxi River, and the average deposition height was $5 \mathrm{~m}$. The debris flows damaged 4240 meters highway, 3130 meters levee, and 233 buildings. The economic loss was 550 million Yuan[1]. the largest and most harmful one is the Bayi gully, causing 2 people lost, 1 people wounded, 140 houses seriously destroyed, DuWen road were silted and check dams, drainage engineering were destroyed. and 15 million (RMB) direct economic lost.

\section{THE HISTORIC RECORDS OF BAYI GULLY DEBRIS FLOW}

Before the Wenchuan Earthquake, There were three times debris flows outbreaks in the historic records of the Bayi Gully [2]. During the period between the Wenchuan earthquake and

October 2010, several debris flows occurred in Bayi gully, on May 14 and May 19,2008 and July 17, 2009. Total volume of debris flow is approximately $1.14 \times 10^{6} \mathrm{~m}^{3}$ [3], About $400 \mathrm{~m}$ of roads and more than 40 houses , 230 people were buried.

On August 13, 2010, the maximum rainfall was $75.0 \mathrm{~mm}$ per hour at 16:00-17:00, then The sediment was easily erosion by flash flood and formed debris flow. The rainfall at 15:00 18:00 on 13th were respectively $21.7 \mathrm{~mm}, 75.0 \mathrm{~mm}, 53.3 \mathrm{~mm}$ per hour [4]. The accumulative rainfall of this debris flow process is $229 \mathrm{~mm}$. the large volume deposits silted in the watercourse, $1150 \mathrm{~m}$ long, average $80 \mathrm{~m}$ wide, average $12 \mathrm{~m}$ thick, the maximum thickness was more than $15 \mathrm{~m}$, and of $1.16 \times 10^{6} \mathrm{~m}^{3}$ total debris flow volume[5]. Causing 2 people are lost, 1 people is wounded, 140 houses are seriously destroyed, DuWen road were silted and check dams, drainage engineering were destroyed (shown in Figure 1). And 15 million direct economic lost.

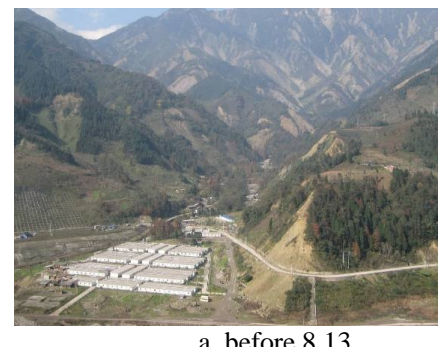

a. before 8.13

FIGURE I. THE DEPOSITION FAN OF DEBRIS FLOW OF BAYI GULLY

\section{BACKGROUND OF BAYI GULLY DEBRIS FLOW}

Longchi Town of Dujiangyan City is located in the Sichuan basin of a semi-tropical moist climatic region, with mild climate, plentiful precipitation and four distinguishable seasons. The average annual precipitation of Dujiangyan City is $1034.8 \mathrm{~mm}$; The average month precipitation is $289.9 \mathrm{~mm}$; the maximum rainfall of $83.9 \mathrm{~mm} / \mathrm{h}$. Longchi Town lies $10 \mathrm{~km}$ away in the north of Dujiangyan City. The rainfall of the town concentrates in three months from July to September, which constitutes more than $80 \%$ of the annual precipitation. The rainfall features of big fluctuation, concentrated precipitation, intensive rainfall and high rainstorm frequency, conduce to the development of disasters such as floods and debris flows etc. Bayi Gully lies in the Longchi Town, The gully trends from 
northwest to southeast. with the catchment area of $8.63 \mathrm{~km}^{2}$, $4.45 \mathrm{~km}$ long in the main channel, the lowest point in the gully mouth at $850 \mathrm{~m}$ altitude, the highest peak at $2456 \mathrm{~m}$ altitude, with the elevation difference of $1606 \mathrm{~m}$; the average longitudinal gradient of the channel $376.7 \%$. It has three branches, of which the west one named Xiaowan gully, the middle one named Xiaogan gully, and the east one named Dagan gully. The Xiaogan gully covers an area of $2.96 \mathrm{~km}^{2}$ and v-shaped transect of channel and 574\% of longitudinal slope, The Xiaowan gully covers an area of $2.09 \mathrm{~km}^{2}$ and $501 \%$ of longitudinal slope, The Dagan gully covers an area of $2.62 \mathrm{~km}^{2}$ and 511\% of longitudinal slope, The channel of Bayi Gully in the drainage area, with steep hillside slopes, deeply cutting-in canyons, short channels, and a v-shaped transect of channel, provides suitable topographic conditions for debris flow outbreaks (shown in Figure 2).

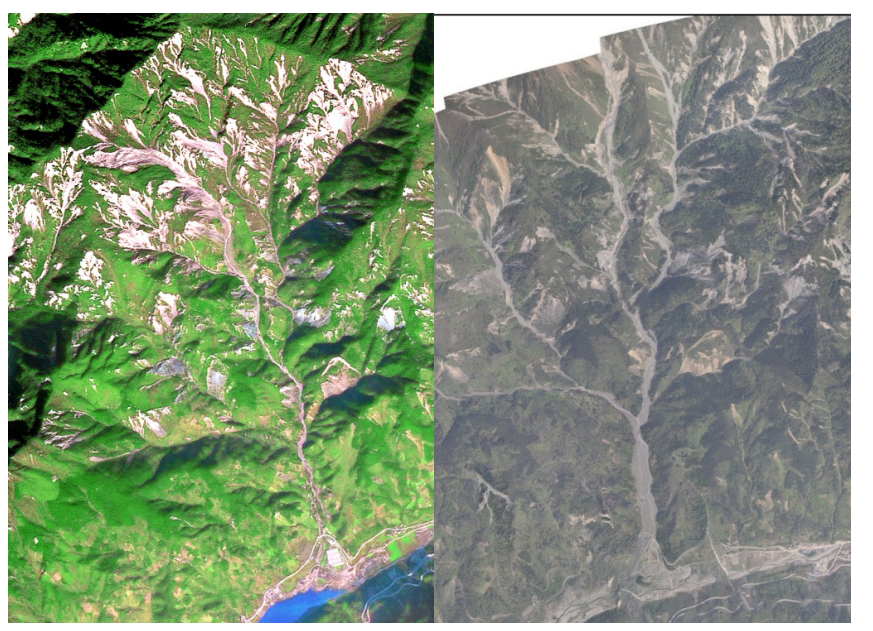

$$
\begin{array}{ll}
\text { a. before } 8.13 & \text { b. after } 8.13
\end{array}
$$

FIGURE II. COMPARISON OF THE BAYI GULLY BEFORE AND AFTER AUGUST 13TH, 2010

The Bayi Gully catchment consists of granites, sandstones, mudstones, shales, andesites, and limestones. The catchment is located in the Wenchuan Earthquake area, and it is crossed by the triggering Yingxiu-Beichuan Fault of this Earthquake. In the survy area, the new tectonic movement is mainly intermittent uplift and the terrain is strongly cut. In addition, the area is an area of intense earthquakes. Based on the modified "China Seismic Zoning Map" (GB18306-2001), the peak acceleration of ground motion was $0.20 \mathrm{~g}$, the ground motion response spectrum characteristic period was $0.40 \mathrm{~s}$, and the degree of seismic intensity was XI in this area.

\section{THE CHARACTERISTICS OF BAYI GUlly DEBRIS FLOW}

With the effect of heavy rainstorms at 16:00 on August 13th, a giant debris flow broke out in the Bayi Gully. Based on the investigation filed, we could determine that the giant flow was not triggered by the main channel but three branches of the channel(Dagan gully, Xiaogan gully and Xiaowan gully).

The main channel is distributed from gully mouth of Bayi Gully to gully mouth of Xiaowan Gully. The debris flow, with the deposits in the course of the main channel, $900 \mathrm{~m}$ long, $80 \mathrm{~m}$ wide, $12 \mathrm{~m}$ thick on the average, the maximum thickness was more than $15 \mathrm{~m}$, the average longitudinal gradient of the channel was $112 \%$, and of $86.4 \times 10^{4} \mathrm{~m}^{3}$ total debris flow volume. Some houses are seriously destroyed and silted in Jianjianshu, the minimum depth of deposit is estimated to be 7.5 m(shown in Figure 3).

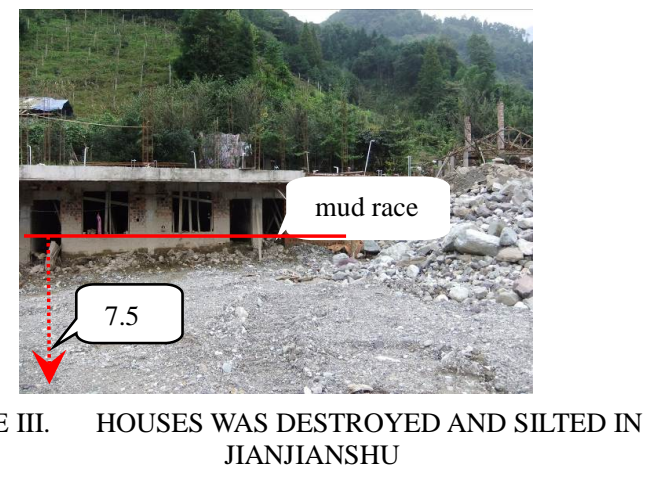

The Xiaowan gully is distributed at 930-1714 m altitude, with the catchment area of $2.09 \mathrm{~km}^{2}$. The main Characteristics of forming region are washing and erosion, the channel is extremely narrow, most parts of which are within $3 \mathrm{~m}$, with the narrowest place of $1.5 \mathrm{~m}$ only. Figure 4 shows that gully washing and erosion is serious, the sediment loading of watershed outlet is obviously added. The main characteristics of pathway region are destroyed and deposition, Figure 5 shows that many trees were destroyed in pathway region. From our field observations, we suggest that the initiation of debris flows in the Xiaowan gully started with significant surface washed and ditch erosion.

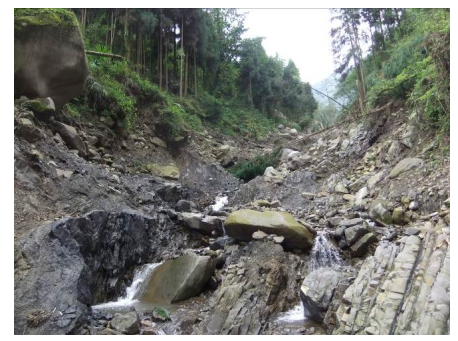

FIGURE IV. WASHING AND EROSION IN FORMING REGION OF XIAOWAN GULLY

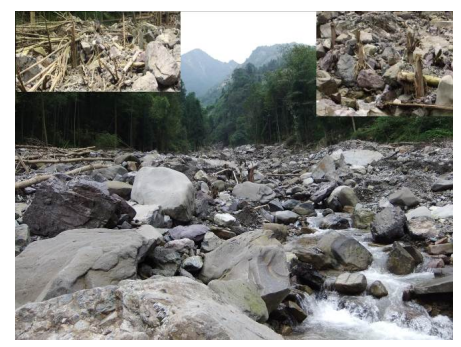

FIGURE V. TREES WERE DESTROYED IN PATHWAY REGION OF XIAOWAN GULLY

The Xiaogan gully is distributed at $1072-2079$ m altitude, with the catchment area of $2.96 \mathrm{~km}^{2}$. The main Characteristics of the one are erosion and blockage. Figure 6shows that highly weathered bedrock and colluviums derived from rock fall and landslides. 


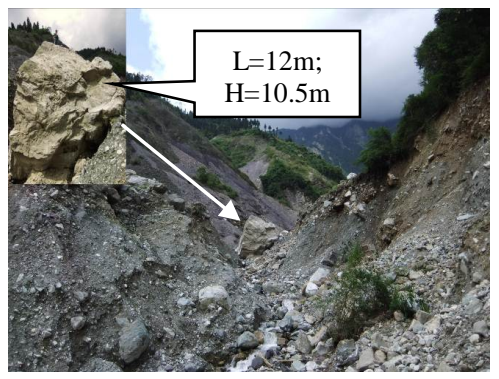

FIGURE VI. THE LARGEST BLOCKS DEPOSITED IN XIAOGAN GULLY

The Dagan gully is distributed at 1072-2436 m altitude, with the catchment area of $2.62 \mathrm{~km}^{2}$. The main Characteristic is blockage. Figure 7 shows that new rockfill dam, From the observations, we concluded the debris flows were initiated by heavy rainfalls and floods broke these dams derived from landslides block channel, formed strong flows, eroded the bed of the channel in the Dagan gully.

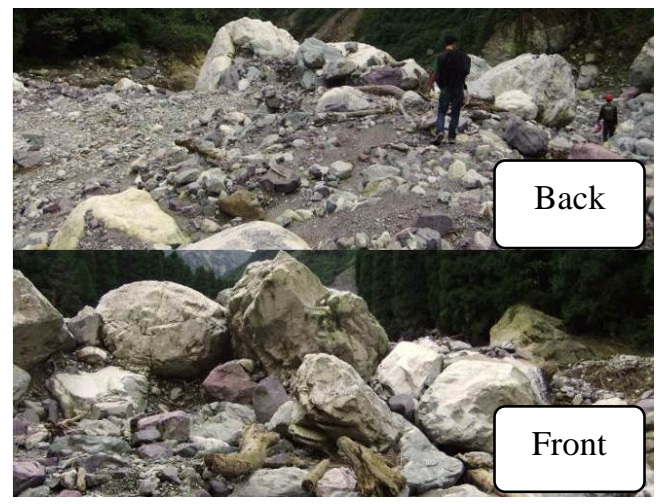

FIGURE VII. NEW NATURAL DAM AND SILTING BEHIND THE DAM IN DAGAN GULLY

\section{THE FORMATION OF BAYI GULLY DEBRIS FLOW}

Generally speaking, the three prerequisites for debris flows are steep topography, an abundance of loose materials, and intense precipitation. From our intensive field observations, we concluded that the initiation of debris flows in the Bayi gully was the comprehensive effect of earthquake and rainfall. The former is a basic condition, which provided an abundance of loose solid materials for debris flows, while the latter was a trigger factor that carried these materials.

The formation condition of debris flow was changed by 39 landslides triggered by the Wenchuan Earthquake. The landslides formed deposited in the catchment of Bayi Gully with the volume of $757.61 \times 10^{4} \mathrm{~m}^{3}$. The sediment, which is loose and its size is small, was easily erosion by flash flood and formed debris flow.

Rainfall is the factor of triggering debris flows in Bayi Gully. The total rainfall during the debris flow of August 13 was $229 \mathrm{~mm}$, and the duration of debris flow was 1 hour40 min. The rainfall at 15:00 - 18:00 on 13th was respectively 22.7 $\mathrm{mm}, 75.0 \mathrm{~mm}, 53.3 \mathrm{~mm}$ per hour.

\section{STATICS AND DYNAMICS CHARACTER OF DEBRIS FLOW}

Statics character and dynamics character of debris flow are key parameters of debris flow features. Through the investigation on the deposits in the accumulative area of debris flow occurred in Bayi Gully on August 13, 2010, it is concluded that: The character of debris flow deposit is of the chaotic one, with obviously reversed deposition of particle sizes, which shows sub-viscous debris flow. According to the sampling (small sample) in deposition area of debris flow on August 13, the density of debris flow can be calculated by particle distribution (shown in Table 1, Figure 8) [6]:

$$
\gamma_{D}=\gamma_{0}+P_{2} P_{05}^{0.35} \gamma_{V}
$$

In which: $\gamma_{D}=$ density of viscous debris flow $\left(\mathrm{g} / \mathrm{cm}^{3}\right) ; \gamma_{V}=$ minimum density of viscous debris flow $\left(=2.0 \mathrm{~g} / \mathrm{cm}^{3}\right) ; \gamma_{0}=$ minimum density of debris flow $\left(=1.5 \mathrm{~g} / \mathrm{cm}^{3}\right) ; \mathrm{P}_{2}=$ content percentage of coarse particles $>2 \mathrm{~mm} ; \mathrm{P}_{05}=$ content percentage of coarse particles $<0.05 \mathrm{~mm}$. The calculation result shows that the density of the August 13 debris flow is $1.88 \mathrm{~g} / \mathrm{cm}^{3}$.

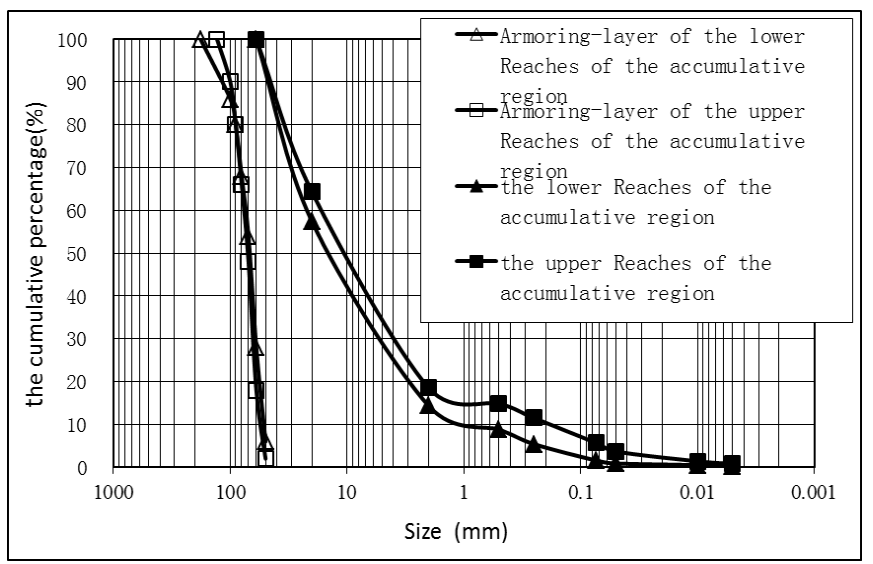

FIGURE VIII. PARTICLE DISTRIBUTIONS OF THE SEDIMENT OF THE ACCUMULATIVE REGION

TABLE I. CACULATION OF DENSITIES OF DEBRIS FLOWS

\begin{tabular}{cccc}
\hline positions & $P_{2} /(\%)$ & $P_{05} /(\%)$ & $\square D /\left(\mathrm{g} \cdot \mathrm{cm}^{-3}\right)$ \\
\hline the upper Reaches & 81.5 & 3.7 & 2.01 \\
\hline the lower Reaches & 85.7 & 0.9 & 1.88
\end{tabular}

The flow velocity, discharge and the total volume of debris are three important parameters to evaluate the degree of risk and prevent debris flow hazards. [7-8]:

$$
\begin{gathered}
V_{C}=\frac{1}{n} R^{2 / 3} \cdot I_{c}^{1 / 2} \\
V_{C}=K \bullet R^{2 / 3} \bullet I_{c}^{1 / 5} \\
V_{C}=1.1 \bullet(g \bullet R)^{2 / 3} \bullet I_{c}^{1 / 3}\left(D_{50} / D_{10}\right)^{1 / 4} \\
Q=A \bullet V_{C} \\
W=0.2 Q \bullet T
\end{gathered}
$$

In where:

n--bed roughness; 
$\mathrm{V}_{\mathrm{c}}$ - the velocity of debris flow $(\mathrm{m} / \mathrm{s})$;

R-- the hydraulic radius (m), (shown in Table 2);

$\mathrm{I}_{\mathrm{c}}$--the slope gradient of channel bed (\%);

$\mathrm{K}_{\mathrm{c}}$-the factor that incorporates debris flow depth, obtained from Table 3.

$\mathrm{D}_{50--}$ the medium particle diameter,which is the particle diameter at the middle of the grading curve $(\mathrm{mm}) ;\left(\mathrm{D}_{50}=10.0\right.$ $\mathrm{mm}$ );

$\mathrm{D}_{10^{--}}$the particle diameter whose accumulative content is $10 \%(\mathrm{~mm}) ;\left(\mathrm{D}_{10}=0.2 \mathrm{~mm}\right)$;

Q-- flow discharge of debris flow $\left(\mathrm{m}^{3} / \mathrm{s}\right)$;

W--total volume of debris blow $\left(\mathrm{m}^{3}\right)$;

$\mathrm{T}$--duration of debris flow (s);

The calculation result can be seen in Table 4 .

TABLE II. PARAMETERS OF THE CROSS-SECTION

\begin{tabular}{cccccc}
\hline positions & $B(\mathrm{~m})$ & $H(\mathrm{~m})$ & $A\left(\mathrm{~m}^{2}\right)$ & $I c(\%)$ & $R$ \\
\hline Xiaogan G. & 12.0 & 4.2 & 42.0 & 208 & 2.33 \\
\hline Dagan G. & 11.5 & 3.1 & 31.5 & 139 & 2.03 \\
\hline Xiaowan G. & 9.3 & 2.5 & 19.2 & 292 & 1.85 \\
\hline
\end{tabular}

TABLE III. RELATIONSHIP BETWEEN THE VELOCITY COEFFICIENT (K) AND DEPTH $(\mathrm{H})$

\begin{tabular}{c|c|c|c|c|c|c|c|c}
\hline$H$ & $<2.5$ & 2.75 & 3.0 & 3.5 & 4.0 & 4.5 & 5.0 & $>5.5$ \\
\hline$K$ & 10.0 & 9.5 & 9.0 & 8.0 & 7.0 & 6.0 & 5.0 & 4.0 \\
\hline
\end{tabular}

TABLE IV. THE VELOCITY AND DISCHARGE CALCULATION OF DEBRIS FLOW

\begin{tabular}{cccccc}
\hline The positions of Cross- & \multicolumn{4}{c}{$\mathrm{Vc}(\mathrm{m} / \mathrm{s})$} & \multicolumn{3}{c}{$Q\left(\mathrm{~m}^{3} / \mathrm{s}\right)$} & $W\left(\mathrm{~m}^{3}\right)$ \\
\cline { 2 - 6 } section & 1) & (2) & (3) & (4) & (5) \\
& & & & & \\
\hline Xiaogan G. & 12.0 & 12.6 & - & $\mathbf{5 0 4}$ & $\mathbf{6 2 . 9}$ \\
\hline Dagan G. & 10.2 & 10.3 & - & $\mathbf{3 2 1}$ & $\mathbf{4 0 . 1}$ \\
\hline Xiaowan G. & 13.8 & 14.4 & - & $\mathbf{2 7 7}$ & $\mathbf{3 4 . 6}$ \\
\hline Bayi G. & - & - & 15.3 & $\mathbf{1 0 8 2}$ & $\mathbf{1 3 5 . 1}$ \\
\hline
\end{tabular}

The total volume of debris flow on August 13th can be concluded as $135.1 \times 10^{4} \mathrm{~m}^{3}$ by calculating the peak discharge of debris flow and outbreak time of debris flow. The result is quite close to the field investigation on total volume of debris flow $116.5 \times 10^{4} \mathrm{~m}^{3}$. Therefore, the value of $1082 \mathrm{~m}^{3} / \mathrm{s}$ and 15.3 $\mathrm{m} / \mathrm{s}$ can be taken as the peak discharge of debris flow in Bayi Gully on August 13.

The yield stress of debris flow is a key parameter to reflect the character of debris flow, especially viscous debris flow. In accordance with the survey on the deposits in debris flow of August 13th, the yield stress of viscous debris flow in Bayi Gully is available [9]:

$$
\tau_{B}=\gamma^{\prime} g h \sin \theta
$$

In which: $\tau_{\mathrm{B}}=$ yield stress of debris fluid $(\mathrm{Pa}) ; \gamma^{\prime}=\left(\gamma_{\mathrm{C}^{-}}\right.$ $\left.\gamma_{0}\right)$,relative density of debris flow $\left(\mathrm{kg} / \mathrm{m}^{3}\right) ; \gamma_{C}=$ density of debris flow $\left(1880 \mathrm{~kg} / \mathrm{m}^{3}\right), \gamma_{0}=$ environment density, in the air $\gamma_{0} \approx 0$, in the water $\gamma_{0}=1000\left(\mathrm{~kg} / \mathrm{m}^{3}\right) ; \mathrm{g}=$ gravity of acceleration $(=9.81$ $\left.\mathrm{m} / \mathrm{s}^{2}\right) ; \theta=$ gradient $(=6.00), \mathrm{h}=$ maximum thickness of deposit of debris flow $(=3.5 \mathrm{~m})$. The result is $\tau_{\mathrm{B}}=6747 \mathrm{~Pa}$. It is one of the reasons why the deposition of the debris flow on August 13th could be filed up in the channel of Bayi gully with the thickness exceeding $7.5 \mathrm{~m}$.

\section{DISCUSSIONS}

Source of solid materials in Bayi debris flow is formed by landslides from Wenchuan Earthquake, i.e. deposition of landslide-debris. A decrease $757.61 \times 10^{4} \mathrm{~m}^{3}$ is found in the deposition in the Bayi gully after the Wenchuan Earthquake, debris flows were triggered four times on May 14 and May 19,2008 and July 17, 2009 and August 13, 2010 in the same gully, The total volume debris flows is approximately $114 \times 10^{4}$ $\mathrm{m}^{3}$ before August 13, 2010 and $116 \times 10^{4} \mathrm{~m}^{3}$ in August 13, 2010. By the comparison and survey on the deposition. There is only $30 \%$ of the total volume of deposition that took away by debris flows and floods. It is shown that there are still lots of loose deposition can form debris flows time after time.

The channel is narrow in the three branches(Dagan gully, Xiaogan gully and Xiaowan gully), most parts of which are within $5 \mathrm{~m}$, with the narrowest place of $2 \mathrm{~m}$ only in Xiaowan gully. The gradient of channel is big in the upstream of channel, about 250 and the minimum is about 6.40 in the downstream. Sediment on the surface of accumulative layer in the channel has comparatively small particle size, and above $50 \%$ of them has the particle size within $50 \mathrm{~mm}-70 \mathrm{~mm}$ (Figure 8). The slope of hillside in the channel is not in a steady state due to the steepness, with the slope gradient of 300-600.Moreover, as the deposit on the slope is quite loose, it is easy to collapse into the channel under the rainfall, and block the gully. Therefore, debris flow will be triggered again in Bayi Gully in the future if the heavy rain comes, and more severe or even giant debris flow will occur when the storm hits there.

The main reasons of formation the giant debris flow in the Bayi Gully on August 13th, 2010 are loose solid material and rain. Now there will still remain a great deal of solid material deposition and the extreme severe debris flow as that on August 13, 2010 may be triggered in the future rainy seasons. So the debris flow disaster should be prevented, and the prevention and control of debris flow of Bayi Gully is a long term task.

\section{ACKNOWLEDGEMENTS}

The paper was supported by Office of Education of SiChuan, (Grant No. 16ZB0407) and The Engineering \&Technology of College of Chengdu University of Technology Foundation (Grant No. C122016020).

\section{REFERENCE}

[1] Yu Bin, Ma Yu, Zhang Jiannan, et al.. The group debris flow hazards after the Wenchuan Earthquake in Longchi, Dujiangyan, Sichuan Province. Journal of Maintain Science 2011, 29(6):738-746.

[2] Shen Junhui, Zhu Rongchen, Liu Weiguo, et al. Possibility geological analysis of Gangou debris flow in Longchi Town in Dujiangyan induced by the Earthquake of May 12 in Wenchuan, Journal of Mountain Science,2008, 26(5):513-517. 
[3] Zhang Ziguang, Zhang Zhiming, Zhang Shunbin. Formation conditions and dynamics features of the debris flow in Bayi Gully in Dujiangyan County, The Chinese Journal of Geological Hazard and Control, 2008,21(1):34-38.

[4] Xu Qiang. The 13 August 2010 catastrophic debris flows in Sichuan Province: characteristics, genetic mechanism and suggestions. Journal of Engineering Geology,2010,18(5): 596-608.

[5] Ma Yu, Yu Bin, Wu Yufu, et al. Research on the disaster of debris flow of Bayi Gully, Longchi, Dujiangyan, Sichuan on August 13,2010. Journal of Sichuan university (Engineering science edition),2011,43(S1):92-98.

[6] Yu Bin. Research on the calculating density by the deposit of debris flows. ACTA Sediment logical SINICA .2008,26(5): 789-796.

[7] Yu Bin. Study on the mean velocity of viscous debris flows.Advances in Earth Science . 2008,23(5):524-532.

[8] Zhang Jiannan, Ma Yu, Zhang Huihui .Study on earthquake debris flow in Dangan Gully, Hongkou, Dujiangyan, Sichuan Province. Journal of Maintain Science 2008,28(5): 624-627.

[9] Yu Bin. Study on the Method for deposition depth calculation of debris flow with different densities. Journal of Disaster Prevention and Mitigation Engineering.2010, 23(2): 78-92. 